\title{
ANALISIS PERBANDINGAN PENERAPAN GOOD CORPORATE GOVERNANCE SEBELUM DAN SESUDAH KONVERSI PADA BANK ACEH SYARIAH
}

\author{
Ranny Sharah ${ }^{1}$, Musfiari Haridhi* ${ }^{* 2}$ \\ ${ }^{1,2}$ Program Studi Akuntansi Fakultas Ekonomi Universitas Syiah Kuala \\ e-mail: rannysharah@yahoo.com ${ }^{1}$,mus_sav@unsyiah.ac.id ${ }^{* 2}$
}

\section{* Corresponding Author}

\begin{abstract}
This study aims to see differences in the implementation of Good Corporate Governance in Bank Aceh Syariah before and after cut off. The type of this study is descriptive qualitative. The object of this study is Good Corporate Governance Bank Aceh Syariah. The type of data is secondary data as corporate annual reports of 2014-2017. The results of this study show that there was no significant difference in the implementation of Good Corporate Governance in Bank Aceh Syariah for the year of this research. The mechanism and tools for the effective implementation of Good Corporate Governance are relatively the same. There was additional organizational structure after cut off in the implementation of Good Corporate Governance with the establishment of a Sharia Supervisory Board, tasked with overseeing the business activities of the bank to fit the Fatwa of The National Sharia Council.
\end{abstract}

Keywords: implementation, Good Corporate Governance, Bank Aceh Syariah

\section{Pendahuluan}

Kelangsungan hidup suatu bank sangat dipengaruhi oleh corporate governance atau tata kelola perusahaan tersebut. Menurut Peraturan Menteri Negara BUMN nomor PER-01/MBU/2011 GCG (Good Corporate Governance) adalah prinsipprinsip yang mendasari suatu proses dan mekanisme pengelolaan perusahaan yang berlandaskan peraturan perundang-undangan dan etika berusaha. Corporate governance merupakan salah satu elemen kunci dalam meningkatkan efisiensi ekonomis, yang meliputi serangkaian hubungan antara manajemen perusahaan, dewan komisaris, para pemegang saham dan stakeholders lainnya.

Isu CG gempar setelah World Bank dan Asian Development Bank (ADB) mengungkapkan bahwa penyebab krisis keuangan yang melanda berbagai negara, terutama di Asia, tak lain adalah buruknya pelaksanaan Corporate Governance. Di Indonesia, krisis ekonomi ini berkembang menjadi krisis multidimensi yang berkepanjangan, karena diikuti krisis politik serta berbagai masalah dalam negeri lainnya. Krisis tersebut terjadi karena banyak perusahaan yang belum menerapkan GCG secara konsisten, khususnya belum diterapkannya etika bisnis (KNKG, 2006:1).

Upaya mengatasi terjadinya krisis akibat lemahnya tata kelola bank, maka dikeluarkan Peraturan Bank Indonesia No.8/14/PBI/2006 tentang Pelaksanaan GCG bagi Bank Umum (Tjondro, 2011) Peraturan Perbankan Indonesia tersebut harus diterapkan oleh semua bank umum yang beroperasi di Indonesia. Sementara itu, ketentuan penerapan GCG bagi Bank Umum Syariah dan Unit Usaha Syariah diatur dalam Peraturan Perbankan Indonesia No. 11/33/PBI/2009.

Pertumbuhan perbankan syariah di Indonesia mengalami kemajuan yang cukup pesat setelah terjadinya krisis ekonomi tersebut. Hal ini berawal dari Bank Muamalat Indonesia, satu-satunya bank syariah yang termasuk kategori bank sehat yang terbukti mampu bertahan. Sadar akan banyaknya peminat yang mulai melirik perbankan syariah, Bank Aceh membuat keputusan untuk mengkonversi sistem bank konvensionalnya menjadi bank syariah untuk menjawab kebutuhan segmen mayoritas masyarakat Aceh

Seiring dengan perkembangan tersebut, satu hal yang perlu dicermati oleh Bank Aceh adalah aspek GCG, mengingat banyaknya kasus yang 
pernah dialami bank tersebut. Mulai dari Direksi Bank Aceh yang tidak lengkap, tersangkut kasus hukum dengan nasabahnya, kredit macet yang bertambah, dan meningkatnya kerugian secara signifikan. Penelusuran yang dilakukan oleh media online Kompasiana (edisi 30 November 2013) menyebutkan, berdasarkan Laporan Publikasi Keuangan Bank Aceh per 30 September 2013, Bank Aceh terlihat melemah dengan labanya yang terus menurun. Tabungan yang anjlok dan kredit macet yang juga meningkat. Kuat dugaan, amburadulnya Bank Aceh disebabkan belum terisinya Direksi secara lengkap dalam satu tahun (2012-2013). Selama posisi Direksi banyak yang kosong laba Bank Aceh per September 2012-2013 anjlok Rp 42,6 miliar, yakni dari Rp 299,916 miliar menjadi Rp 257,303 miliar. Jumlah tabungan menurun dari Rp 3,317 triliun menjadi Rp 2,743 triliun. Kredit macet/kredit bermasalah juga meningkat dari 3,94\% menjadi 4,06\%.

Menurut informasi yang dihimpun Serambi (edisi 2 September 2013), di tahun 2012 Bank Aceh Cabang Lhokseumawe mengalami sejumlah kasus, dua diantaranya adalah kredit bermasalah $\mathrm{Rp} 7,5$ miliar dengan terdakwa yang berinisial EB (Pemimpin Bank Aceh Cabang Lhokseumawe), dan kasus kredit macet Rp 1,5 miliar dengan terdakwa yang berinisial AA dan EB (Kabag Kredit dan Pemimpin Bank Aceh Cabang Lhokseumawe). Peristiwa ini terjadi pada saat periode Bank Aceh masih menganut pola konvensional

Di tahun 2017 Bank Aceh kembali diterpa kasus pembobolan dana dengan modus kredit fiktif yang menimpa Bank Aceh Syariah Cabang Tamiang. Terdapat enam tersangka dalam kasus ini. Tersangka utama yaitu AL, mantan bendahara SMPN 2 Kejuruan Muda Lima tersangka lainnya merupakan karyawan Bank Aceh Cabang Tamiang, yaitu $\mathrm{Hj}$. Ma, Rd, AR, IDY, dan If. Akibat perbuatan para tersangka, Bank Aceh mengalami kerugian sebesar Rp 2,249 miliar (Serambi edisi 28 April 2017).

Implementasi GCG sangat penting untuk pencapaian kinerja bank, karena pada dasarnya didesain untuk melindungi kepentingan stakeholders maupun shareholders. Bank Aceh berkomitmen untuk memastikan penerapan GCG sesuai dengan tujuan dan diimplementasikan dengan tepat. Menjadi pionir sebagai bank pemerintah yang berlabel syariah membuat Bank Aceh memiliki tanggung jawab besar untuk menunjukkan kemajuan dan perkembangan yang baik.

\section{Kerangka Teoritis Stewardship Theory}

Teori ini dibangun berdasarkan atas asumsi filosofis mengenai sifat manusia yakni bahwa manusia pada hakikatnya dapat dipercaya, mampu bertindak dengan penuh tanggung jawab, memiliki integritas dan kejujuran terhadap pihak lain. Stewardship theory memandang bahwa para manajer dipercaya mampu bertindak sedemikian rupa untuk mencapai kinerja tinggi demi kepentingan publik maupun stakeholder (Jefri, 2018). Dengan kata lain, stewardship theory menyatakan bahwa manajemen memiliki peranan penting dalam memaksimalkan keuntungan serta keberhasilan perusahaan dan pencapaian good corporate governance

\section{Sistem Perbankan \\ Perbankan Konvensional}

Pada Pasal 1 Undang-Undang No. 10 Tahun 1998 tentang Perbankan disebutkan bahwa bank adalah badan usaha yang menghimpun dana dari masyarakat dalam bentuk simpanan dan menyalurkannya kepada masyarakat dalam bentuk kredit dan/atau bentuk-bentuk lainnya dalam rangka meningkatkan taraf hidup rakyat banyak. Bank konvensional adalah bank yang menjalankan kegiatan usahanya secara konvensional yang terdiri atas Bank Umum Konvensional dan Bank Perkreditan Rakyat.

Pada bank konvensional, mekanisme pemerolehan pendapatan menggunakan sistem bunga, yaitu sistem yang menjanjikan pihak yang menyimpan atau menyalurkan dananya dengan persentase tertentu terhadap dana yang dialokasikan. Dengan demikian, pemerolehan pendapatan oleh penabung atas uang yang ditabungnya tidak memiliki kaitan dengan pendapatan yang diperoleh bank dari mekanisme penyaluran dananya. Dalam hal ini, nasabah bisa langsung menghitung pendapatan yang akan diterimanya dari bank pada saat menyimpan uang (Yaya et al, 2013: 51). 


\section{Perbankan Syariah}

Pada Pasal 1 Undang-Undang No. 21 Tahun 2008 tentang Perbankan Syariah menyebutkan bahwa Perbankan Syariah adalah segala sesuatu yang menyangkut tentang Bank Syariah dan Unit Usaha Syariah, mencakup kelembagaan, kegiatan usaha, serta cara dan proses dalam melakukan kegiatan usahanya. Bank syariah adalah bank yang menjalankan kegiatan usahanya berdasarkan prinsip syariah yang terdiri atas Bank Umum Syariah (BUS) dan Bank Pembiayaan Rakyat Syariah (BPRS).

Menurut Muhammad (2014:15) bank syariah merupakan lembaga keuangan yang usaha pokoknya memberikan pembiayaan dan jasa-jasa lainnya dalam lalu lintas pembayaran serta peredaran uang yang pengoperasiannya disesuaikan dengan prinsip syariat Islam. Perbankan syariah dalam menjalankan kegiatan usahanya tidak dapat dipisahkan dari konsep-konsep syariah yang mengatur produk dan operasionalnya.

Penyaluran dana bank syariah, secara garis besar memiliki pilihan produk pembiayaan syariah yang terbagi menjadi empat prinsip, yaitu prinsip jual beli, prinsip sewa, prinsip bagi hasil, dan akad pelengkap. Prinsip jual beli dilaksanakan karena adanya perpindahan kepemilikan barang atau benda, transaksi jual beli terdiri dari pembiayaan murabahah, salam dan istishna. Prinsip sewa dilaksanakan karena adanya perpindahan manfaat yang mana objek transaksinya adalah jasa. Prinsip bagi hasil terdiri dari pembiayaan musyarakah dan mudharabah. Akad pelengkap terdiri dari hiwalah, rahn, qardh, wakalah, kafalah (Karim, 2004 dalam Ascarya, 2005:19)

\section{Bank Aceh Syariah}

Bank Aceh merupakan bank daerah milik

Pemerintah Provinsi Aceh yang didirikan pada tahun 1973, yang pada awal berdirinya bank ini bernama Bank Pembangunan Daerah Istimewa Aceh (BPDI Aceh). Pemerintah Daerah telah beberapa kali mengadakan perubahan Peraturan Daerah (Perda), yaitu mulai Perda No.10 Tahun 1974, Perda No. 6 Tahun 1978, Perda No. 5 Tahun 1982, Perda No. 8 Tahun 1988, Perda No. 3 Tahun 1993 dan terakhir Perda No. 2 Tahun 1999 tentang Perubahan Bentuk Badan Hukum Bank Pembangunan Daerah Istimewa Aceh menjadi PT Bank Pembangunan Daerah Istimewa Aceh, yang telah disahkan oleh Menteri
Dalam Negeri dengan Keputusan Menteri Dalam Negeri Nomor: 584.21.343 Tahun 1999.

Berdasarkan Akta Notaris Husni Usman tentang Pernyataan Keputusan Rapat No. 10 tanggal 15 Desember 2008, modal dasar kembali ditingkatkan menjadi Rp1,5 triliun dan dilakukan perubahan nama Perseroan menjadi PT. Bank Aceh. Perubahan tersebut telah disahkan oleh Menteri Hukum dan Hak Asasi Manusia Republik Indonesia No. AHU44411.AH.01.02 Tahun 2009. Perubahan nama menjadi PT. Bank Aceh telah disahkan oleh Keputusan Gubernur Bank Indonesia No.12/61/KEP.GBI/2010 tanggal 29 September 2010.

Melalui hasil rapat RUPSLB (Rapat Umum Pemegang Saham Luar Biasa) dan berdasarkan Keputusan Dewan Komisioner OJK Nomor. KEP4/D.03/2016 Bank Aceh melakukan perubahan kegiatan usaha dari sistem konvensional menjadi sistem syariah seluruhnya. Cut off sistem konvensional PT. Bank Aceh dilakukan pada tanggal 16 September 2016. pada tanggal 19 September 2016 perubahan sistem operasional dilaksanakan secara serentak pada seluruh jaringan kantor Bank Aceh. Sejak tanggal tersebut segala aktivitas dan usaha yang dijalankan harus berdasarkan prinsip syariah (www.bankaceh.co.id).

\section{Good Corporate Governance \\ Pengertian Good Corporate Governance}

Menurut Arafat (2006) istilah GCG (Good Corporate Governance) pertama kali diperkenalkan oleh Cadbury Committee pada tahun 1922 yang mendefinisikan GCG sebagai berikut:

The system by which organization are directed and controlled or a set of rule that define the relationship between shareholders, managers, creditors, the goverment, employee, and other internal and external stakeholders in respect to their rights and responsibilities

Setelah dikenalkan oleh Cadbury Committee, berkembanglah berbagai definisi berkenaan dengan GCG. Definisi Good Corporate Governance (GCG) menurut Bank Dunia adalah aturan, standar dan organisasi di bidang ekonomi yang mengatur perilaku pemilik perusahaan, direktur dan manajer serta perincian dan penjabaran tugas dan wewenang serta 
pertanggung jawabannya kepada investor (pemegang saham dan kreditur) (Wibowo, 2014).

Di Indonesia penerapan prinsip GCG dimulai sejak menandatangani letter of intent (LOI) dengan IMF (International Monetary Fund), yang salah satu bagian pentingnya adalah pencantuman jadwal perbaikan pengelolaan perusahaan-perusahaan di Indonesia. Sejalan dengan hal tersebut, Komite Nasional Kebijakan Governance (KNKG) berpendapat bahwa perusahaan-perusahaan di Indonesia mempunyai tanggung jawab untuk menerapkan standar GCG yang telah ditetapkan standar internasional (Sutedi, 2011:3).

Dengan demikian, GCG adalah suatu sistem yang mengatur, mengelola dan mengawasi proses pengendalian usaha untuk menaikkan nilai saham, sekaligus sebagai bentuk perhatian kepada para pemangku kepentingan. Tantangan yang muncul dalam GCG adalah mencari cara untuk memaksimumkan penciptaan kesejahteraan sedemikian rupa sehingga tidak membebani ongkos yang tidak perlu kepada pihak ketiga atau masyarakat.

\section{Prinsip-Prinsip Good Corporate Governance}

Ada empat komponen utama yang diperlukan dalam konsep good corporate governance, (Kaen, 2003; Shaw, 2003 dalam Kaihatu, 2006) yaitu fairness, transparency, accountability, dan responsibility. Keempat komponen tersebut penting karena penerapan prinsip good corporate governance secara konsisten terbukti dapat meningkatkan kualitas laporan keuangan dan juga dapat menjadi penghambat aktivitas rekayasa kinerja yang mengakibatkan laporan keuangan tidak menggambarkan nilai fundamental perusahaan. Prinsip-prisnip tersebut antara lain:

1. Transparency (keterbukaan informasi) yaitu keterbukaan dalam mengemukakan informasi yang material dan relevan serta keterbukaan dalam proses pengambilan keputusan

2. Accountability (akuntabilitas) yaitu kejelasan fungsi dan pelaksanaan pertanggungjawaban organisasi bank, sehingga pengelolaannya berjalan secara efektif

3. Responsibility (pertanggungjawaban) yaitu kesesuaian pengelolaan bank dengan peraturan perundang-undangan yang berlaku dan prinsipprinsip pengelolaan bank yang sehat
4. Fairness (kewajaran) yaitu keadilan dan kesetaraan dalam memenuhi hak-hak stakeholders yang timbul berdasarkan perjanjian dan peraturanperundang-undangan yang berlaku

Menurut Keputusan Menteri Badan Usaha Milik Negara Nomor: KEP-117/M-MBU/2002 bahwa di samping keempat prinsip di atas, masih ada satu prinsip tambahan lagi, yaitu prinsip independency (kemandirian). Prinsip ini diartikan sebagai suatu keadaan di mana perusahaan dikelola secara profesional tanpa benturan kepentingan dan pengaruh/tekanan dari pihak manapun yang tidak sesuai dengan peraturan perundang-undangan yang berlaku dan prinsip-prinsip korporasi yang sehat

\section{Tujuan Good Corporate Governance}

\begin{tabular}{|c|c|}
\hline $\begin{array}{c}\text { PBI No. } 8 / 14 / \mathrm{PBI} / 2006 \\
\text { Penerapan GCG bagi Bank Umum }\end{array}$ & $\begin{array}{c}\text { PBI No. 11/33/PBI/2009 } \\
\text { Penerapan GCG bagi BUS dan UUS }\end{array}$ \\
\hline $\begin{array}{l}\text { a. Melindungi kepentingan seluruh } \\
\text { pihak yang memiliki kepentingan } \\
\text { secara langsung atau tidak langsung } \\
\text { terhadap kegiatan usaha bank umum } \\
\text { (stakeholders). } \\
\text { b. Meningkatkan kinerja bank umum. } \\
\text { c. Meningkatkan kepatuhan terhadap } \\
\text { peraturan perundang-undangan serta } \\
\text { nilai etika (code of conduct) yang } \\
\text { berlaku pada lembaga perbankan. } \\
\text { d. Memperkuat kondisi internal } \\
\text { perbankan nasional dengan } \\
\text { Arsitektur Perbankan Indonesia. }\end{array}$ & $\begin{array}{l}\text { a. Mewujudkan tata kelola perbankan } \\
\text { syariah yang berlandaskan pada } \\
\text { transparansi, akuntabilitas, } \\
\text { pertanggungjawaban, profesional, dan } \\
\text { kewajaran. } \\
\text { b. Memenuhi prinsip syariah, sehingga } \\
\text { reputasi perbankan syariah tetap } \\
\text { terjaga. } \\
\text { c. Membangun lembaga perbankan yang } \\
\text { sehat dan tangguh. } \\
\text { d. Meningkatkan kepatuhan terhadap } \\
\text { peraturan perundang-undangan serta } \\
\text { nilai etika yang berlaku pada lembaga } \\
\text { perbankan syariah. } \\
\text { e. Meningkatkan perlindungan seluruh } \\
\text { pihak yang memiliki kepentingan } \\
\text { secara langsung maupun tidak } \\
\text { langsung terhadap kegiatan dan } \\
\text { kelangsungan usaha perbankan syariah } \\
\text { (stakeholders). } \\
\text { f. Dalam rangka perbaikan dan } \\
\text { peningkatan kualitas pelaksanaan GCG } \\
\text { melalui self assessment secara } \\
\text { komprehensif terhadap pelaksanaan } \\
\text { GCG, sehingga dapat dilakukan } \\
\text { langkah perbaikan yang diperlukan. } \\
\text { g. Dalam rangka melakukan check and } \\
\text { balance di antara kelembagaan } \\
\text { perbankan syariah. }\end{array}$ \\
\hline
\end{tabular}

\section{Manfaat Penerapan Good Corporate Governance}

Menurut Forum Corporate Governance in Indonesia (FCGI) ada beberapa manfaat yang dapat kita ambil dari penerapan GCG yang baik, antara lain

1. Meningkatkan kinerja perusahaan melalui terciptanya proses pengambilan keputusann yang lebih baik, meningkatkan efisiensi operasional perusahaan serta lebih meningkatkan pelayanan kepada stakeholders 
2. Mempermudah diperolehnya dana pembiayaan yang lebih murah sehingga dapat lebih meningkatkan corporate value

3. Mengembalikan kepercayaan investor untuk menanamkan modalnya di Indonesia

4. Pemegang saham akan merasa puas dengan kinerja perusahaan karena sekaligus akan meningkatkan stakeholders value dan dividen

\section{Kerangka Pemikiran}

Berdasarkan landasan teori yang telah dipaparkan diatas, maka kerangka dalam penelitian ini menggambarkan secara sistematik mengenai bagaimana penerapan GCG Bank Aceh pada saat sistem operasional konvensional dan saat sistem operasional syariah. Semua komponen yang tertera di skema dianalisis untuk membuktikan adanya perbedaan GCG yang diterapkan pada Bank Aceh Syariah sebelum dan sesudah dilakukan konversi. Skema kerangka pemikiran dapat dilihat pada Gambar 2

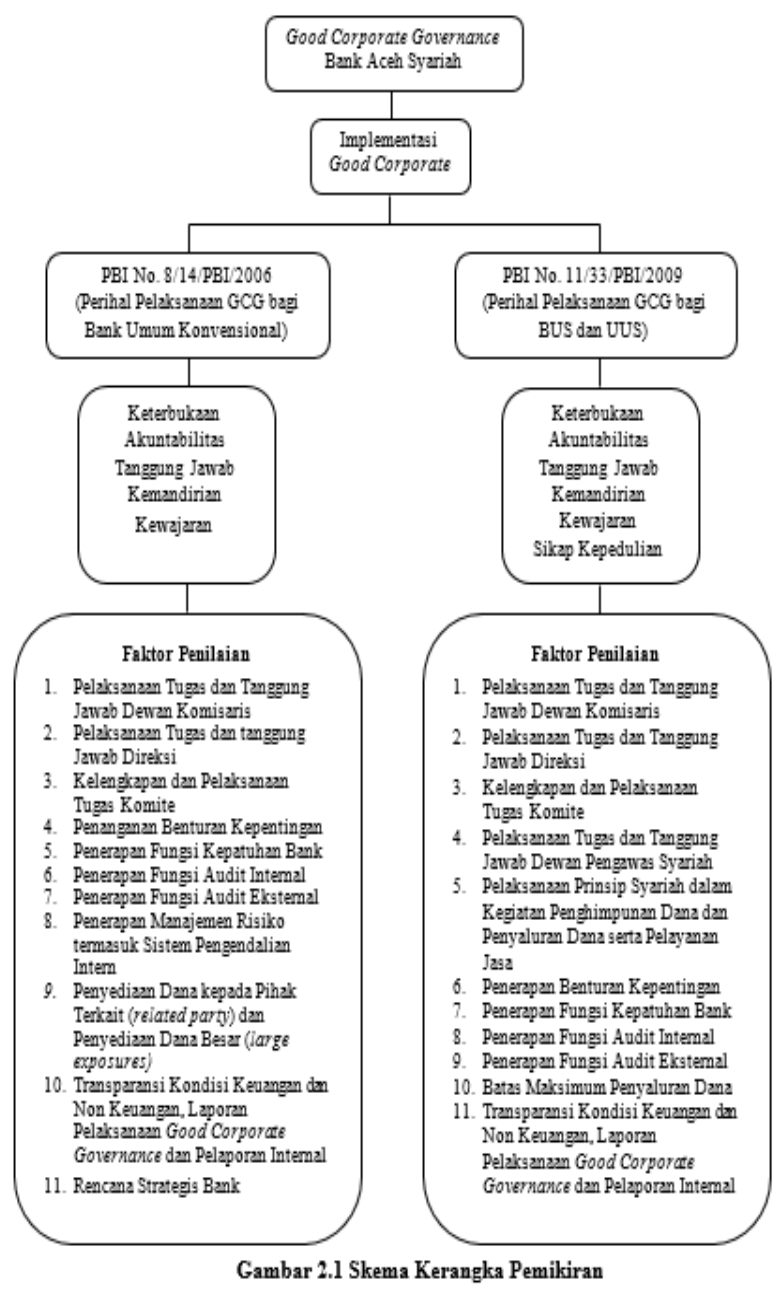

\section{Metode Penelitian \\ Desain Penelitian}

Menurut Sekaran dan Bougie (2013:134) desain penelitian harus memiliki 6 aspek penting yaitu:

1. Tujuan Penelitian

Penelitian ini bertujuan untuk membuktikan adanya perbedaan pada good corporate governance yang diterapkan pada Bank Aceh Syariah sebelum dan sesudah dilakukan konversi dengan menggunakan metode analisis deskriptif. Metode ini dipilih karena dianggap lebih sesuai untuk menjelaskan atau menggambarkan variabel yang diteliti yaitu good corporate governance

2. Jenis Penelitian

Penelitian ini menggunakan jenis penelitian deskriptif kualitatif dengan metode analisis

3. Situasi Studi

Situasi dalam penelitian ini tidak teratur, yaitu situasi atau kondisi yang tidak diatur berdasarkan keterlibatan peneliti dan kondisi dari lingkungan penelitian, sehingga tidak adanya tindakan campur tangan terhadap rutinitas kinerja yang rutin

4. Tingkat Intervensi

Tingkat intervensi dalam penelitian ini adalah intervensi minimal, dimana peneliti tidak memiliki kemampuan atau wewenang untuk melakukan intervensi terhadap kegiatan apapun yang dilakukan oleh bank terkait, hanya dapat mengumpulkan data yang diperlukan dan menganalisis

5. Unit Analisis

Unit analisis mengacu pada tingkat kesatuan data yang dikumpulkan dan digunakan selama tahap analisis data. Unit analisis dalam penelitian ini adalah organisasi, yaitu Bank Aceh Syariah

6. Horizon Waktu

Horizon waktu dalam penelitian ini berupa runtut waktu (time series). Periode data yang digunakan yaitu selama kurun waktu 4 tahun (20142017), yang berupa 2 tahun laporan tahunan konvensional (2014-2015) dan 2 tahun laporan tahunan syariah (2016-2017) 


\section{Objek Penelitian}

Sugiyono (2015:38) mendefinisikan objek penelitian sebagai suatu atribut atau sifat atau nilai dari orang, objek atau kegiatan yang mempunyai variasi tertentu yang ditetapkan oleh peneliti untuk dipelajari dan kemudian ditarik kesimpulannya. Pada penelitian ini, lingkup objek penelitian yang ditetapkan sesuai dengan permasalahan yang akan diteliti adalah mengenai good corporate governance Bank Aceh Syariah pada saat sebelum dan sesudah konversi

\section{Sumber dan Teknik Pengumpulan Data}

Data yang digunakan dalam penelitian ini merupakan data sekunder, yaitu berupa dokumen dan laporan-laporan tertulis yang berhubungan dengan penelitian, yang telah dikumpulkan oleh para peneliti terdahulu, yang sudah diterbitkan, dan tidak perlu dikumpulkan lagi oleh peneliti sekarang (Sekaran dan Bougie, 2013:180). Data yang digunakan berupa laporan GCG Bank Aceh Syariah pada periode 20142017. Data tersebut diperoleh dari laporan tahunan (annual report) Bank Aceh Syariah.

Teknik pengumpulan data dilakukan dengan pendokumentasian laporan tahunan bank yang diperoleh melalui situs resmi Bank Aceh Syariah. Dokumentasi adalah mencari dan mengumpulkan data yang berkaitan dengan objek penelitian, yang berupa catatan, transkip, buku, jurnal, surat kabar dan berbagai situs penunjang lainnya

\section{Model Analisis}

Penelitian ini menggunakan metode analisis deskriptif yaitu metode yang bertujuan mendeskripsikan atau memberi gambaran terhadap suatu objek penelitian yang diteliti melalui sampel atau data yang telah terkumpul dan membuat kesimpulan yang berlaku umum.

Adapun prosedur sebelum menganalisis data dalam penelitian ini adalah sebagai berikut:

1. Mengumpulkan data-data perusahaan, terutama yang berhubungan dengan Good Corporate Governance

2. Peninjauan penerapan Good Corporate Governance berdasarkan aspek-aspek pelaksanaan Good Corporate Governance

3. Menganalisa data tersebut dengan berpedoman pada aspek-aspek Good Corporate Governance yang sesuai dengan PBI No. 8/14/PBI/2006 dan PBI No. 11/33/PBI/2009

4. Kesimpulan berdasarkan hasil analisis, apakah terdapat perbedaan yang signifikan pada penerapan Good Corporate Governance saat sebelum dan sesudah konversi pada Bank Aceh Syariah

\section{Hasil dan Pembahasan \\ Hasil Penelitian}

Penelitian mendeskriptifkan perbedaan good corporate governance Bank Aceh Syariah pada saat sebelum dan sesudah dilakukan konversi. Penelitian dilakukan terhadap laporan tahunan bank selama 4 tahun seperti yang telah dijelaskan pada pembahasan desain penelitian. Hasil penelitian menunjukkan bahwa Bank Aceh Syariah memiliki tingkatan nilai komposit yang berbeda dari keempat tahun tersebut seperti yang ditunjukkan dalam Tabel 1 .

Tabel 1

Index Self Asessment GCG Score Bank Aceh selama 4 tahun

\begin{tabular}{|l|c|c|c|c|}
\hline \multirow{2}{*}{\multicolumn{1}{|c|}{ Tahun }} & \multicolumn{2}{c|}{ Konvensional } & \multicolumn{2}{c|}{ Syariah } \\
\cline { 2 - 5 } & $\mathbf{2 0 1 4}$ & $\mathbf{2 0 1 5}$ & $\mathbf{2 0 1 6}$ & $\mathbf{2 0 1 7}$ \\
\hline Index Self Asessment GCG Score & 1,78 & 1,95 & 1,63 & 2,58 \\
\hline Rata-Rata & \multicolumn{3}{|c|}{1,86} & \multicolumn{2}{c|}{2,10} \\
\hline Predikat & 2 & 2 & 2 & 3 \\
\hline Sumber: Data diolah (2019)
\end{tabular}

Berdasarkan hasil self assessment GCG pada Bank Aceh Syariah periode 2014-2017 nilai rata-rata GCG Bank Aceh pada saat sistem operasional konvensional sebesar 1,86 lebih baik dari sistem operasional syariah yang memiliki nilai GCG sebesar 2,10. Hal ini menunjukkan bahwa penerapan GCG Bank Aceh saat sistem operasional konvensional lebih baik dibandingkan saat sistem operasional syariah.

Namun, apabila melihat kriteria dari peraturan Bank Indonesia bahwa dari nilai rata-rata GCG Bank Aceh baik saat sebelum maupun sesudah konversi dapat dikategorikan dengan predikat "BAIK" meskipun belum memenuhi kriteria GCG di bawah 1,5 .

\section{Pembahasan}

Penerapan Good Corporate Governance pada Bank Aceh Syariah

Secara umum, konsep dan prinsip good corporate governance pada bank konvensional dapat menjadi acuan teoritis pada bank syariah. Akan tetapi 
good corporate governance tersebut harus distandarisasikan dengan nilai-nilai Islam. Adanya Dewan Pengawas Syariah (DPS) yang menjadi pembeda antara struktur organisasi dalam bank syariah dan bank konvensional. Dewan Pengawas Syariah bertugas melakukan pengkajian atas produk dan jasa bank, serta mengawasi kegiatan usaha bank agar sesuai dengan ketentuan dan prinsip syariah yang telah difatwakan oleh Dewan Syariah Nasional dan Majelis Ulama Indonesia.

Pada saat sistem operasional konvensional prinsip good corporate governance terdiri dari transparency, accountability, responbility, independency dan fairness. Tetapi pada sistem operasional syariah, prinsip independency digantikan dengan prinsip profesional. Dari kelima prinsip tersebut, Bank Aceh Syariah memiliki satu tambahan prinsip, yaitu social awarness (sikap kepedulian). Maksudnya adalah bentuk kepedulian Bank Aceh Syariah terhadap masyarakat yang kurang beruntung dan lingkungan, yang dilakukan dengan berbagai bentuk kegiatan kemanusiaan dan sosial, seperti kepedulian terhadap masyarakat dalam meningkatkan pendidikan, kesehatan masyarakat yang tidak mampu dan pembangunan fasilitas keagamaan.

\section{Perbedaan Good Corporate Governance Saat Sebelum dan Sesudah Konversi pada Bank Aceh Syariah}

\section{Analisis Self Assessment GCG Bank Aceh Syariah Tahun 2014-2015}

1. Pelaksanaan Tugas dan Tanggung Jawab Dewan Komisaris.

Penilaian kinerja Dewan Komisaris dilakukan oleh pemegang saham yang dievaluasi berdasarkan pengawasan terhadap realisasi Kebijakan Umum Direksi, self assessment GCG, dan pertanggung jawaban laporan tahunan dan laporan kerja bank. Dari hasil self assessment GCG tahun 2014-2015, Dewan Komisaris dinilai telah melaksanakan tugas dan tanggung jawabnya dengan baik dan mengimplementasikan prinsipprinsip GCG dalam menjalankan fungsi pengawasan bank. Hal ini terbukti dari peringkat 2 yang diperoleh pada faktor ini

2. Pelaksanaan Tugas dan Tanggung Jawab Direksi

Penilaian kinerja Direksi dilakukan oleh Dewan Komisaris dan pemegang saham yang dievaluasi berdasarkan kriteria yang disusun oleh Komite Nominasi dan Remunerasi. Penilaian dilakukan pada tiap akhir periode tutup buku. Pada self assessment tahun 2014 dan 2015 faktor ini memperoleh peringkat 2 , yang artinya Direksi telah melaksanakan tugas dan tanggung jawabnya dengan baik, mampu bertindak dan mengambil keputusan secara independen dan mengimplementasikan prinsip- prinsip GCG sesuai dengan ketentuan yang berlaku

3. Kelangkapan dan Pelaksanaan Tugas Komite Bank Aceh Syariah telah membentuk Komite untuk mendukung pelaksanaan tugas dan tanggung jawab Dewan Komisaris dan/atau Direksi dan telah memenuhi persyaratan dengan baik. Penilaian kinerja Komite Dewan Komisaris dilakukan oleh Dewan Komisaris, dan penilaian kinerja Komite Direksi dilakukan oleh Direksi. Pada self assessment tahun 2014 dan 2015 faktor ini memperoleh peringkat 2, yang artinya komposisi dan kompetensi anggota

Komite telah memenuhi persyaratan yang diperlukan dan telah menjalankan tugas dan tanggung jawabnya dengan efektif

4. Penanganan Benturan Kepentingan

Bank Aceh Syariah telah memiliki kebijakan, sistem dan prosedur penanganan benturan kepentingan yang sangat lengkap dan sangat efektif. Hal ini terbukti pada self assessment tahun 2014 faktor ini memperoleh peringkat 1. Faktor ini mengalami penurunan peringkat pada tahun 2015 menjadi peringkat 2, artinya efektivitas kebijakan, sistem dan prosedur penanganan benturan kepentingan mengalami penurunan

5. Penerapan Fungsi Kepatuhan Bank

Pada hasil self assessment tahun 2014 dan 2015 faktor ini memperoleh peringkat 2, yang artinya pelaksanaan tugas dan independensi Direktur Kepatuhan berjalan efektif dan Kepatuhan Bank dinilai tergolong baik. Pelaksanaan fungsi kepatuhan dilakukan oleh Direktur Kepatuhan yang dirangkum dalam Laporan Kepatuhan dan diserahkan kepada Direktur Utama dan Dewan Komisaris

6. Penerapan Fungsi Audit Intern 
Penilaian fungsi audit intern dilakukan oleh Komite Audit dan laporan hasil audit diserahkan kepada Direksi serta Komisaris. Hasil self assessment tahun 2014 dan 2015 menunjukkan faktor ini memperoleh peringkat 2, yang artinya Bank Aceh Syariah telah menerapkan fungsi audit intern dengan baik dan pelaksanaannya didukung oleh personil yang memiliki kompetensi di bidangnya

7. Penerapan Fungsi Audit Ekstern

Penunjukkan Kantor Akuntan Publik
dilakukan sesuai rekomendasi dari Komite Audit. Untuk tahun buku 2014 dan 2015, Bank Aceh Syariah menetapkan KAP Hertanto, Sidik \& Indra sebagai auditor Independen. Faktor ini mengalami peningkatan peringkat pada tahun 2015, yaitu dari peringkat 2 pada tahun 2014 menjadi peringkat 1 pada tahun 2015, yang artinya pelaksanaan audit oleh Akuntan Publik sangat efektif dan telah sesuai dengan persyaratan yang ditetapkan dalam ketentuan

8. Penerapan Fungsi Manajemen Risiko Termasuk Sistem Pengendalian Internal

Dalam rangka efektivitas fungsi manajemen risiko, Bank Aceh telah menetapkan beberapa strategi dan kebijakan, serta telah membentuk tim Counterpart Review Kebijakan Manajemen Risiko. Dewan Komisaris dan Direksi telah menetapkan Komite Manajemen Risiko dan Anggota Komite Pemantau Risiko. Kebijakan penetapan limit dan toleransi risiko ditetapkan melalui Rapat Komite Manajemen Risiko. Hal ini dapat dilihat berdasarkan hasil self assessment tahun 2014 dan 2015 yang memperoleh peringkat 2 pada faktor ini

9. Prinsip Kehati-hatian dalam Penyediaan Dana Kepada Pihak Terkait dan Penyediaan Dana Besar Bank Aceh telah melakukan aktifitas penyaluran kredit kepada masyarakat, termasuk kepada pihak yang terkait dengan Bank dan penyediaan dana besar kepada debitur inti. Berdasarkan hasil self assessment pada tahun 2014 memperoleh peringkat 1 dan pada tahun 2015 memperoleh peringkat 2, Bank Aceh dinilai telah menerapkan prinsip kehatihatian dengan baik dalam penyediaan dana kepada pihak terkait
10. Transparansi Kondisi Keuangan dan Non Keuangan Laporan Pelaksanaan GCG dan Pelaporan Internal

Bank Aceh Syariah telah melaksanakan transparansi kondisi keuangan dan nonkeuangan dengan sangat baik. Bank Aceh Syariah telah menyampaikan laporan keuangan dan nonkeuangan, laporan GCG dan laporan lainnya kepada stackeholders tepat pada waktunya. Hal ini dapat dilihat berdasarkan hasil self assessment tahun 2014 dan 2015 yang memperoleh peringkat 2 pada faktor ini

11. Rencana Strategis Bank

Dalam mendukung penerapan GCG, Bank Aceh telah menyusun Rencana Korporasi yang terkait dengan laporan pelaksanaan GCG. Rencana Korporasi ini terdiri dari rencana jangka pendek yang dijabarkan dalam Rencana Kerja Anggaran Tahunan, rencana jangka menengah yang dijabarkan dalam Rencana Bisnis Bank (RBB), dan rencana jangka panjang yang dijabarkan dalam Rencana Lima Tahun (Corporate Plan) yang mana pelaksanaannya dipantau dan dievaluasi oleh Dewan Komisaris. Hal ini dapat dilihat berdasarkan hasil self assessment tahun 2014 yang memperoleh peringkat 1, dan pada tahun 2015 mengalami penurunan peringkat menjadi peringkat 2 dimana susunan Rencana Strategis Bank tidak dilampirkan

\section{Analisis Self Assessment GCG Bank Aceh Syariah Tahun 2016-2017}

1. Pelaksanaan Tugas dan Tanggung Jawab Dewan Komisaris

Dari hasil self assessment GCG tahun 2016-2017. Dewan Komisaris dinilai telah melaksanakan tugas dan tanggung jawabnya dengan baik dan mengimplementasikan prinsip-prinsip GCG dalam menjalankan fungsi pengawasan bank. Hal ini terbukti dari peringkat 2 yang diperoleh pada faktor ini

2. Pelaksanaan Tugas dan Tanggung Jawab Direksi Faktor ini mengalami penurunan peringkat pada tahun 2017 yaitu dari peringkat 1 pada tahun 2016 menjadi peringkat 3 pada tahun 2017, yang artinya pelaksanaan tugas dan tanggung jawab Direksi berjalan cukup efektif namun 
terdapat kelemahan- kelemahan yaitu adanya penyimpangan internal

3. Kelangkapan dan Pelaksanaan Tugas Komite Faktor ini memperoleh peringkat 2 pada tahun 2016-2017, yang artinya komposisi dan kompetensi anggota Komite telah memenuhi persyaratan yang diperlukan dan telah menjalankan tugas dan tanggung jawabnya dengan efektif

4. Pelaksanaan Tugas dan Tanggung Jawab Dewan Pengawas Syariah

Penilaian kinerja DPS dilakukan oleh Rapat Umum Pemegang Saham (RUPS) yang dievaluasi berdasarkan laporan pengawasan DPS yang diserahkan pada stakeholder. Pada tahun 2016 faktor ini memperoleh peringkat 1, yang artinya DPS telah melakukan tugas dan tanggung jawabnya dengan sangat baik. Namun, faktor ini mengalami penurunan peringkat pada tahun 2017 yaitu mencapai peringkat 3, dimana pada tahun 2017 Laporan Hasil Pengawasan DPS secara semesteran tidak dilampirkan

5. Pelaksanaan Prinsip Syariah dalam Kegiatan Penghimpunan Dana dan Penyaluran Dana serta Pelayanan Jasa

Produk penghimpunan dana, penyaluran dana serta pelayanan jasa yang diluncurkan Bank Aceh Syariah telah melalui opini DPS atas kesesuaian produk terhadap Prinsip Syariah. Hal ini terbukti dari peringkat 2 yang diperoleh pada tahun 2016. Namun, pada tahun 2017 faktor ini memperoleh peringkat 3 , yang artinya efektivitas pelaksanaan prinsip syariah dalam kegiatan penghimpunan dana, penyaluran dana, dan pelayanan jasa mengalami penurunan

6. Penanganan Benturan Kepentingan

Berdasarkan self assessment secara umum penanganan benturan kepentingan telah dilaksanakan dengan baik, hal ini terbukti pada tahun pada tahun 2016-2017 memperoleh peringkat 2 . Artinya, selama periode tersebut tidak terdapat transaksi yang mengandung benturan kepentingan

7. Penerapan Fungsi Kepatuhan Bank

Pada hasil self assessment tahun 2016 faktor

ini memperoleh peringkat 1 , yang artinya pelaksanaan tugas dan independensi Direktur
Kepatuhan berjalan sangat efektif dan Kepatuhan Bank dinilai tergolong sangat baik. Faktor ini mengalami penurunan peringkat pada tahun 2017 menjadi peringkat 3, dimana Kepatuhan Bank dinilai cukup baik namun pernah melakukan pelanggaran terhadap ketentuan dan komitmen yang telah dibuat. Pelaksanaan fungsi kepatuhan dilakukan oleh Direktur Kepatuhan yang dirangkum dalam Laporan Kepatuhan dan diserahkan kepada Direktur Utama dan Dewan Komisaris

8. Penerapan Fungsi Audit Intern

Hasil self assessment tahun 2016 menunjukkan faktor ini memperoleh peringkat 2, yang artinya Bank Aceh Syariah telah menerapkan fungsi audit intern dengan baik dan pelaksanaannya didukung oleh personil yang memiliki kompetensi di bidangnya. Namun, pada tahun 2017 mengalami penurunan peringkat menjadi peringkat 3 , dimana terdapat penyimpangan internal yaitu kasus pembobolan dana yang dilakukan oleh karyawan tetap Bank Aceh Syariah Cabang Tamiang

9. Penerapan Fungsi Audit Ekstern

Bank Aceh Syariah menetapkan KAP Helianto \& Rekan untuk tahun buku 2016 dan 2017. Penunjukkan Kantor Akuntan Publik dilakukan sesuai rekomendasi dari Komite Audit. Faktor ini mengalami penurunan peringkat pada tahun 2017, yaitu dari peringkat 1 pada tahun 2016 menjadi peringkat 2 pada tahun 2017, dimana Rekapitulasi Monitoring Tindak Lanjut Audit dan Rekapitulasi Monitoring Tindak Lanjut Reviu Proyek tidak dilampirkan

10. Batas Maksimum Penyaluran Dana

Pada tahun 2016 dan 2017 faktor ini memperoleh peringkat 2, yang artinya Bank Aceh Syariah telah menerapkan prinsip kehatihatian dan manajemen risiko dengan baik dalam penyediaan dana kepada pihak terkait. Kebijakan dan prosedur terkait penyediaan dana dilakukan sesuai dengan perkembangan peraturan dan perundang-undangan yang berlaku

11. Transparansi Kondisi Keuangan dan Non Keuangan, Laporan Pelaksanaan GCG dan Pelaporan Internal 
Hasil self assessment pada tahun 2016 menunjukkan faktor ini memperoleh peringkat 2, artinya Bank Aceh Syariah telah melaksanakan transparansi kondisi keuangan dan non-keuangan dengan sangat baik. Bank Aceh Syariah telah menyampaikan laporan keuangan dan non-keuangan, laporan GCG dan laporan lainnya kepada stackeholders tepat pada waktunya. Namun, pada tahun 2017 faktor ini memperoleh peringkat 3, dimana tingkat transparansi bank dalam menyampaikan informasi dan penggunaan data mengalami penurunan

Hasil analisis menunjukkan bahwa mekanisme dan alat penerapan GCG yang efektif relatif sama. Sehingga dapat disimpulkan bahwa pada GCG Bank Aceh saat sebelum dan sesudah konversi tidak terdapat perbedaan yang signifikan. Artinya, Bank Aceh telah melaksanakan self assessment secara konsisten. Meskipun telah melakukan konversi dan memiliki Dewan Pengawas Syariah, namun pelaksanaannya masih kurang efektif

\section{Kesimpulan, Keterbatasan dan Saran}

\section{Kesimpulan}

Berdasarkan hasil analisis yang telah dilakukan, maka dapat disimpulkan bahwa:

1) Penerapan GCG pada Bank Aceh Syariah lebih baik pada saat menganut sistem operasional konvensional. Hal ini dilihat dari nilai rata-rata GCG Bank Aceh, dimana saat sistem operasional konvensional memperoleh nilai sebesar 1,86 dibandingkan saat sistem operasional syariah yang memperoleh nilai sebesar 2,10.

2) Adanya tambahan struktur organisasi sesudah konversi dalam penerapan GCG, yaitu dengan dibentuknya Dewan Pengawas Syariah yang bertugas mengawasi kegiatan usaha bank agar sesuai dengan Fatwa Dewan Syariah NasionalMajelis Ulama Indonesia.

3) Penerapan GCG Bank Aceh Syariah saat sebelum dan sesudah konversi pada tahun periode penelitian ini tidak terdapat perbedaan yang signifikan. Mekanisme dan ketentuan pelaksanaan GCG yang efektif relatif sama

\section{Keterbatasan}

Beberapa keterbatasan dari penelitian ini adalah:

1) Penilaian kinerja hanya dilakukan selama 2 tahun saja, sehingga kurang terlihatnya perkembangan-perkembangan signifikan yang terjadi pada Bank Aceh Syariah secara menyeluruh

2) Penelitian ini hanya dilakukan selama 2 tahun sebelum konversi dan 2 tahun sesudah konversi, sehingga kurang terlihatnya peningkatan penerapan GCG pada Bank Aceh Syariah

\section{Saran}

Berdasarkan hasil analisis dan kesimpulan yang didapat dalam penelitian ini, maka saran-saran yang dapat dikemukakan adalah sebagai berikut:

1) Untuk pihak Bank Aceh Syariah mekanisme pengendalian internal lebih ditingkatkan lagi, sehingga diharapkan ke depannya tidak terulang lagi kasus penyimpangan internal.

2) Untuk peneliti selanjutnya:

a. Diharapkan dapat menambahkan periode penelitian dan menggunakan metode yang lain untuk menilai GCG, agar didapatkan hasil yang lebih maksimal dan lebih menggambarkan perbedaan yang signifikan pada GCG bank konvensional dan bank syariah.

b. Diharapkan untuk meneliti dan menganalisis lebih spesifik lima prinsip utama GCG yaitu transparency, accountability, responsibility, fairness, dan independency serta kendala- kendala yang dihadapi dalam penerapan GCG

\section{Daftar Pustaka}

Aceh Tribunnews. (2013). Mata Ungkap Kasus Kredit Macet. Melalui <http://aceh.tribunnews.com/2013/09/02/mataungkap-kasus-kredit-macet>. Diakses 27 Juli 2018

Arafat, Wilson. 2006. Manajemen Perbankan Indonesia Teori dan Implementasi. Pustaka LP3ES Indonesia. Jakarta.

Ascarya, \& Diana Yumanita. 2005. Bank Syariah: Gambaran Umum. Jakarta: Pusat Pendidikan dan Studi Kebanksentralan.

Bank Aceh. (2018). Sejarah Singkat. Melalui $<$ http://bankaceh.co.id/?page-id=82>. Diakses 
15 Mei 2018.

Daniri, Mas Ahmad. 2005. Good Corporate Governance: Konsep dan Penerapannya di Indonesia. Jakarta: Ray Indonesia.

Darmawati, Deni dkk. 2004. Hubungan Corporate Governance dan Kinerja Perusahaan. Simposium Nasional Akuntansi VII, Denpasar, 23 Desember 2004.

Effendi, Muh. Arief. 2009. The Power of Good Corporate Governance: Teori dan Implementasi. Jakarta: Salemba Empat

Ikhsan, Arfan dan Herkulanus Bambang Suorasto.2008. Teori Akuntansi dan Riset Multi Paradigma. Yogyakarta: Graha Ilmu.

Jefri, Riny. 2018. Teori Stewardship dan Good Governance. Jurnal Riset Edisi XXVI UNIBO, Vol. 4 No. 003: 14-28, Makassar.

Kaihatu, Thomas S. 2006. Good Corporate Governance dan Penerapannya di Indonesia.Jurnal Manajemen dan Kewirausahaan Vol.8 No.1: 1-9.

Komite Nasional Kebijakan Corporate Governance, 2006, Pedoman Good Corporate Governance Perbankan Indonesia.

Kompasiana. (2015). Bank Aceh Sakit Parah Rugi Rp 42,6 Miliar dan Kredit Macet Naik ke Posisi 4,06 Persen. Melalui <https://www.kompasiana.com/ruslan./5528c3 c06ea8340f3f8b4597/bank-aceh-sakit-parahrugi-rp-42-6-miliar-dan-kredit-macet-naik-keposisi-4-06-persen>. Diakses Juli 2018.

Moeljono, Djokosantoso. 2005. Good Corporate Culture Sebagai Inti dari Good Corporate Governance. Jakarta: Elex Media Komputindo.
Peraturan Bank Indonesia (PBI) No. 11/33/PBI/2009 tentang Pelaksanaan Good Corporate Governance bagi Bank Umum Syariah dan Unit Usaha Syariah.

Peraturan Bank Indonesia (PBI) No. 8/14/PBI/2006 tanggal 6 Oktober 2006 tentang Pelaksanakan Prinsip-prinsip Good Corporate Governance bagi Bank Umum.

Sekaran, Uma \& Roger Bogie. 2013. Research Methods for Business. Sixth Edition.United Kingdom: John Wiley \& Sons Ltd.

Sugiyono. (2015). Metode Penelitian Kuantitatif Kualitatif dan $R \& D$. Bandung: Alfabeta.

Sulaiman, Maliah, Norakma Abd Majid, \& Noraini Mohd Arifin. 2015. Corporate Governance of Islamic Financial Institutions in Malaysia. Asian Journal of Business and Accounting 8(1): 65-93.

Sutedi, Adrian. 2011. Good Corporate Governance. Jakarta: Sinar Grafika.

Tjondro, David, \& R. Wilopo. 2011. Pengaruh Good Corporate Governance (GCG) terhadap Profitabilitas dan Kinerja Saham Perusahaan Perbankan yang Tercatat di Bursa Efek Indonesia. Journal of Business and Banking I No.1:1

Undang-undang No. 21 Tahun 2008 tentang Perbankan Syariah.

Yaya, Rizal, Aji Erlangga Martawireja, \& Ahim Abdurahim. 2016. Akuntansi Perbankan Syariah. Edisi 2. Jakarta: Salemba Empat. 
Lampiran 1

\section{Lampiran 1}

Perhitungan Nilai Komposit GCG Tahun 2014

\begin{tabular}{|c|c|c|c|c|}
\hline No & Faktor Penilaian & $\begin{array}{l}\text { Skor } \\
(1-5)\end{array}$ & Bobot & $\begin{array}{c}\text { Skor } \\
\text { Terbobot }\end{array}$ \\
\hline 1 & $\begin{array}{l}\text { Pelaksanaan Tugas dan Tanggung Jawab } \\
\text { Dewan Komisaris }\end{array}$ & 2 & $10 \%$ & 0,20 \\
\hline 2 & $\begin{array}{l}\text { Pelaksanaan Tugas dan Tanggung Jawab } \\
\text { Direksi }\end{array}$ & 2 & $20 \%$ & 0,40 \\
\hline 3 & Kelengkapan dan Pelaksanaan Tugas Komite & 2 & $10 \%$ & 0,20 \\
\hline 4 & Penanganan Benturan Kepentingan & 1 & $10 \%$ & 0,10 \\
\hline 5 & Penerapan Fungsi Kepatuhan Bank & 2 & $5 \%$ & 0,10 \\
\hline 6 & Penerapan Fungsi Audit Intern & 2 & $5 \%$ & 0,10 \\
\hline 7 & Penerapan Fungsi Audit Ekstern & 2 & $5 \%$ & 0,10 \\
\hline 8 & $\begin{array}{l}\text { Penerapan Fungsi Manajemen Risiko Termasuk } \\
\text { Sistem Pengendalian Intern }\end{array}$ & 2 & $7,5 \%$ & 0,15 \\
\hline 9 & $\begin{array}{l}\text { Prinsip Kehati-hatian dalam Penyediaan Dana } \\
\text { Kepada Pihak Terkait dan Penyediaan Dana } \\
\text { Besar }\end{array}$ & 1 & $7,5 \%$ & 0,075 \\
\hline 10 & $\begin{array}{l}\text { Transparansi Kondisi Keuangan dan Non } \\
\text { Keuangan, Laporan Pelaksanaan GCG } \\
\text { dan Laporan Internal }\end{array}$ & 2 & $15 \%$ & 0,30 \\
\hline 11 & Rencana Strategis Bank & 1 & $5 \%$ & 0,05 \\
\hline \multicolumn{3}{|c|}{ Total Skor } & $100 \%$ & 1,78 \\
\hline \multicolumn{3}{|c|}{ Peringkat } & & \\
\hline
\end{tabular}

Sumber: Data diolah (2019) 
Lampiran 2

Lampiran 2

Perhitungan Nilai Komposit GCG Tahun 2015

\begin{tabular}{|c|c|c|c|c|}
\hline No & Faktor Penilaian & $\begin{array}{l}\text { Skor } \\
(1-5)\end{array}$ & Bobot & $\begin{array}{c}\text { Skor } \\
\text { Terbobot }\end{array}$ \\
\hline 1 & $\begin{array}{l}\text { Pelaksanaan Tugas dan Tanggung Jawab } \\
\text { Dewan Komisaris }\end{array}$ & 2 & $10 \%$ & 0,20 \\
\hline 2 & $\begin{array}{l}\text { Pelaksanaan Tugas dan Tanggung Jawab } \\
\text { Direksi }\end{array}$ & 2 & $20 \%$ & 0,40 \\
\hline 3 & Kelengkapan dan Pelaksanaan Tugas Komite & 2 & $10 \%$ & 0,20 \\
\hline 4 & Penanganan Benturan Kepentingan & 2 & $10 \%$ & 0,20 \\
\hline 5 & Penerapan Fungsi Kepatuhan Bank & 2 & $5 \%$ & 0,10 \\
\hline 6 & Penerapan Fungsi Audit Intern & 2 & $5 \%$ & 0,10 \\
\hline 7 & Penerapan Fungsi Audit Ekstern & 1 & $5 \%$ & 0,05 \\
\hline 8 & $\begin{array}{l}\text { Penerapan Fungsi Manajemen Risiko } \\
\text { Termasuk Sistem Pengendalian Intern }\end{array}$ & 2 & $7,5 \%$ & 0,15 \\
\hline 9 & $\begin{array}{l}\text { Prinsip Kehati-hatian dalam Penyediaan Dana } \\
\text { Kepada Pihak Terkait dan Penyediaan Dana } \\
\text { Besar }\end{array}$ & 2 & $7,5 \%$ & 0,15 \\
\hline 10 & $\begin{array}{l}\text { Transparansi Kondisi Keuangan dan Non } \\
\text { Keuangan, Laporan Pelaksanaan GCG dan } \\
\text { Laporan Internal }\end{array}$ & 2 & $15 \%$ & 0,30 \\
\hline 11 & Rencana Strategis Bank & 2 & $5 \%$ & 0,10 \\
\hline \multicolumn{3}{|c|}{ Total Skor: } & $100 \%$ & 1,95 \\
\hline \multicolumn{2}{|c|}{ Peringkat: } & \multicolumn{3}{|l|}{2} \\
\hline
\end{tabular}

Sumber: Data diolah (2019) 
Lampiran 3

Lampiran 3

Perhitungan Nilai Komposit GCG Tahun 2016

\begin{tabular}{|c|l|c|c|c|}
\hline No & \multicolumn{1}{|c|}{ Faktor Penilaian } & $\begin{array}{c}\text { Skor } \\
(\mathbf{1 - 5})\end{array}$ & Bobot & $\begin{array}{c}\text { Skor } \\
\text { Terbobot }\end{array}$ \\
\hline 1 & $\begin{array}{l}\text { Pelaksanaan Tugas dan Tanggung Jawab } \\
\text { Dewan Komisaris }\end{array}$ & 2 & $12,5 \%$ & 0,25 \\
\hline 2 & $\begin{array}{l}\text { Pelaksanaan Tugas dan Tanggung Jawab } \\
\text { Direksi }\end{array}$ & 1 & $17,5 \%$ & 0,175 \\
\hline 3 & Kelengkapan dan Pelaksanaan Tugas Komite & 2 & $10 \%$ & 0,20 \\
\hline 4 & $\begin{array}{l}\text { Pelaksanaan Tugas dan Tanggung Jawab } \\
\text { Dewan Pengawas Syariah }\end{array}$ & 1 & $10 \%$ & 0,10 \\
\hline 5 & $\begin{array}{l}\text { Pelaksanaan Prinsip Syariah dalam Kegiatan } \\
\text { Penghimpunan Dana dan Penyaluran Dana } \\
\text { serta Pelayanan Jasa }\end{array}$ & 2 & $5 \%$ & 0,10 \\
\hline 6 & Penanganan Benturan Kepentingan & 2 & $10 \%$ & 0,20 \\
\hline 7 & Penerapan Fungsi Kepatuhan Bank & 1 & $5 \%$ & 0,05 \\
\hline 8 & Penerapan Fungsi Audit Internal & 2 & $5 \%$ & 0,10 \\
\hline 9 & Penerapan Fungsi Audit Eksternal & 1 & $5 \%$ & 0,05 \\
\hline 10 & Batas Maksimum Penyaluran Dana & 2 & $5 \%$ & 0,10 \\
\hline 11 & $\begin{array}{l}\text { Transparansi Kondisi Keuangan dan Non } \\
\text { Keuangan, Laporan Pelaksanaan GCG } \\
\text { dan Laporan Internal }\end{array}$ & 2 & $15 \%$ & 0,30 \\
\hline Total Skor: & $\mathbf{2}$ & $\mathbf{1 0 0 \%}$ & $\mathbf{1 , 6 3}$ \\
\hline Peringkat: & & \\
\hline
\end{tabular}

Sumber: Data diolah (2019) 
Lampiran 4

\section{Lampiran 4}

Perhitungan Nilai Komposit GCG Tahun 2017

\begin{tabular}{|c|l|c|c|c|}
\hline No & \multicolumn{1}{|c|}{ Faktor Penilaian } & $\begin{array}{c}\text { Skor } \\
\text { (1-5) }\end{array}$ & Bobot & $\begin{array}{c}\text { Skor } \\
\text { Terbobot }\end{array}$ \\
\hline 1 & $\begin{array}{l}\text { Pelaksanaan Tugas dan Tanggung Jawab } \\
\text { Dewan Komisaris }\end{array}$ & 2 & $12,5 \%$ & 0,25 \\
\hline 2 & $\begin{array}{l}\text { Pelaksanaan Tugas dan Tanggung Jawab } \\
\text { Direksi }\end{array}$ & 3 & $17,5 \%$ & 0,525 \\
\hline 3 & Kelengkapan dan Pelaksanaan Tugas Komite & 2 & $10 \%$ & 0,20 \\
\hline 4 & $\begin{array}{l}\text { Pelaksanaan Tugas dan Tanggung Jawab } \\
\text { Dewan Pengawas Syariah }\end{array}$ & 3 & $10 \%$ & 0,30 \\
\hline 5 & $\begin{array}{l}\text { Pelaksanaan Prinsip Syariah dalam Kegiatan } \\
\text { Penghimpunan Dana dan Penyaluran Dana } \\
\text { serta Pelayanan Jasa }\end{array}$ & 3 & $5 \%$ & 0,15 \\
\hline 6 & Penanganan Benturan Kepentingan & 2 & $10 \%$ & 0,20 \\
\hline 7 & Penerapan Fungsi Kepatuhan Bank & 3 & $5 \%$ & 0,15 \\
\hline 8 & Penerapan Fungsi Audit Internal & 3 & $5 \%$ & 0,15 \\
\hline 9 & Penerapan Fungsi Audit Eksternal & 2 & $5 \%$ & 0,10 \\
\hline 10 & Batas Maksimum Penyaluran Dana & 2 & $5 \%$ & 0,10 \\
\hline 11 & $\begin{array}{l}\text { Transparansi Kondisi Keuangan dan Non } \\
\text { Keuangan, Laporan Pelaksanaan GCG dan } \\
\text { Laporan Internal }\end{array}$ & 3 & $15 \%$ & 0,45 \\
\hline Total Skor & $\mathbf{3}$ & $\mathbf{1 0 0 \%}$ & $\mathbf{2 , 5 8}$ \\
\hline Peringkat & & \multicolumn{2}{|l}{} \\
\hline
\end{tabular}

Sumber: Data diolah (2019) 